\title{
Features of heat and mass transfer at drying of ceramic products with overglaze paints
}

\author{
O.M. Nedbailo (0000-0003-1416-9651), O.G. Chernyshyn (0000-0001-7702-894X) \\ The State Enterprise "Engineering Center "Drying”, Institute of Engineering Thermophysics of NAS of Ukraine, \\ str. Bulakhovskogo, 2, Bldg. 2, Kyiv, 03164, Ukraine \\ Tel.: +380444240279, tel./fax +380444243283 \\ E-mail:icsushka@gmail.com
}

Article info: received 02.03.2021, revised 30.03.2021, accepted 05.05.2021

Nedbailo, O.M., Chernyshyn, O.G. (2021) Features of heat and mass transfer at drying of ceramic products with overglaze paints 2(51), doi: 10.26909/csl.2.2021.1

The basic results of researches of process of a heat exchange are instanced and parsed at drying glasour ceramic colors. Character of change of importance number of Rebinder is established at drying colors and dependence of intensity of a heat dissipation on velocity of air is spotted.

The main results of researches of heat and mass transfer process at drying of overglaze ceramic paints in a stream of drying agent are resulted and analyzed. The nature of the change in the value of the Rebinder number for drying paints is established and the dependence of the heat transfer intensity on the air velocity is determined. Analysis of the temperature coefficient of drying and Rebinder's number determined the directions of heat consumption in the drying process of overglaze ceramic paints.

It is established that the heat flux density depends on the temperature and velocity of the coolant and does not depend on the chemical composition of the paints.

It is shown that the heat transfer coefficient depends on the velocity of the coolant. Compared with heat transfer during laminar flow around the plate during drying, the intensity of heat transfer increases by $75 \%$.

Key words: drying glasour ceramic colors, heat and mass transfer process at drying of overglaze ceramic paints.

\section{Особливості тепломасообміну при сушінні керамічних виробів із надглазурними фарбами}

\author{
О.М. Недбайло, О.Г. Чернишин
}

Державне підприсмство «Інженерний иеентр «Суика»» Інституту технічної теплофізики НАН України, Київ, Україна

Наведені та проаналізовані основні результати досліджень процесу тепломасообміну при сушінні надглазурних керамічних фарб в потоці сушильного агента. Встановлено характер зміни значення числа Ребіндера для сушіння фарб та визначена залежність інтенсивності тепловіддачі від швидкості повітря. Аналіз температурного коефіцієнту сушіння і числа Ребіндера визначив напрямки витрат теплоти в процесі сушіння надглазурних керамічних фарб.

Встановлено, що густина теплового потоку залежить від температури і швидкості теплоносія і не залежить від хімічного складу фарб.

\section{Вступ}

При використанні керамічної глазурованої плитки для внутрішнього облицювання приміщень ве- лика увага приділяється колірній гамі і якості облицювальної плитки. Одним із способів підвищення привабливості глазурованої плитки є їі декорування шляхом нанесення на поверхню надглазурних (ке- 
рамічних) фарб із подальшим сушінням та закріпленням під флюсом низькотемпературним випалом при температурах $600-850{ }^{\circ} \mathrm{C}$.

Процес сушіння різноманітних матеріалів, в тому числі і надглазурних фарб, є достатньо складним тепло- і масообмінним процесом, що потребує досконального експериментального вивчення 3 метою визначення його основних закономірностей.

Мета роботи полягає у знаходженні визначальних коефіцієнтів тепло- і масопереносу при числовому розв'язанні системи диференціальних рівнянь, запропонованих А.В. Ликовим [1] для описання складних процесів тепломасообміну при сушінні.

\section{Матеріали та методи дослідження}

При сушінні надглазурних керамічних фарб до поверхні матеріалу підводиться тепловий потік, що призводить до нагрівання шару фарби та випаровування вологи з неї. Густина теплового потоку, що витрачається на нагрівання шару фарби, визначається співвідношенням

$$
q_{\text {нагр. }}=\bar{c} \cdot g \cdot \frac{d \bar{t}}{d \tau},
$$

де $\bar{c}$ - питома теплоємність вологої фарби, кДж/(кг·К); $t$ - температура, ${ }^{\circ} \mathrm{C} ; g=\frac{G_{\text {a.c. }}}{S_{\text {вол. }}}-$ відношення маси абсолютно сухої фарби до поверхні вологого шару фарби; $\tau$ - проміжок часу, с.

При цьому нехтується зміна товщини шару фарби (усадка) під час сушіння.

Густина теплового потоку, що витрачається на випаровування вологи з шару фарби, може бути знайдена за виразом

$$
q_{\text {вun } .}=r \cdot g \cdot \frac{d \bar{U}}{d \tau}
$$

де $r$ - питома теплота випаровування, кДж/кг.

У відповідності до закону збереження енергії питомий тепловий потік на одиницю поверхні тіла [1]

$$
q(\tau)=r g \frac{d \bar{U}}{d \tau}+\bar{c} g \frac{d \bar{t}}{d \tau}=g r \frac{d \bar{U}}{d \tau}\left(1+\frac{\bar{c}}{r} \frac{d \bar{t}}{d \bar{U}}\right)
$$

Величина $\frac{d \bar{t}}{d \bar{U}}$ визначає зміну середньої температури матеріалу, що припадає на одиницю зміни його середнього вологовмісту за нескінченно малий проміжок часу.

$$
b=\frac{d \bar{t}}{d \bar{U}}
$$

де $b$ - температурний коефіцієнт сушіння.
Під «вологовмістом» в нашому випадку розуміється кількість органічного розчинника в надглазурній муфельній фарбі Instant Color® Plus виробництва Німеччини, що розчиняється в водорозчинному препараті, так званому в'яжучому Decoflux WB 683.

Як було встановлено [2], керамічна плитка має здатність поглинати вологу з повітря. Причому, цей процес протікає досить інтенсивно. Під час сушіння надглазурної муфельної фарби випаровується не тільки розчинник 3 шару фарби, але і волога 3 керамічної плитки [3]. Тому для одержання дійсної кривої сушіння досліди проводилися на скляних плитках розмірами 60х240 мм.

На висушену скляну плитку через трафарет наносилася надглазурна фарба певного кольору. Розміри шару фарби 240х50 мм. Товщина шару фарби залишалась незмінною і залежала від номера сита в трафареті. Для сита №77 товщина нанесеного шару фарби становила 70 мкм.

Порівняння кривих сушіння, одержаних за допомогою ваг і за допомогою тепломасометричного пристрою [4] проведено для чорної фарби.

Слід зазначити, що за допомогою ваг одержується середньоінтегральна по довжині пластини крива сушіння, а при використанні тепломасометричного пристрою одержується три криві сушіння, по кількості датчиків теплового потоку, розташованих по довжині пластини, тобто три криві сушіння для кожного досліду на різних ділянках пластини [5].

\section{Результати та їх обговорення}

Характер змін температурного коефіцієнту сушіння представлений на рис. 1. Як видно 3 нього, величина температурного коефіцієнту сушіння на початку процесу знижується до постійної величини, а при досягненні третього критичного значення відносної вологості $W_{\mathrm{k} 3}=9 \%$ величина $b$ стрімко зростає до значень 70 - 80.

В рівнянні (3) величина $\frac{\bar{c}}{r} \cdot \frac{d \bar{t}}{d \bar{U}} \in$ безрозмірною величиною (число Ребіндера). Вона визначає відношення кількості теплоти, що йде на нагрівання матеріалу, який висушується, до кількості теплоти, що витрачається на випаровування рідини 3 матеріалу за нескінченно малий проміжок часу.

Для органічного розчинника число Ребіндера має вигляд, що представлений на рис. 2. На початку процесу сушіння відбувається прогрівання матеріалу, і число Ребіндера знижується. В процесі сушіння його значення зменшується до мінімальної величини. Це вказує на те, що теплота витрачається на випаровування розчинника 3 шару фарби. При досягненні третього критичного значення від- 
носної вологості $W_{\mathrm{k} 3}=9 \%$ температура матеріалу стрімко зростає та, відповідно, збільшується число Ребіндера. Це свідчить про те, що на заключній стадії процесу сушіння теплота витрачається на нагрівання матеріалу, а не на випаровування 3 нього рідини, як і в разі випаровування вологи із капілярно-пористих матеріалів. Тому процес сушіння керамічних фарб закінчується при досягненні $9 \%$ відносної вологості. Це дозволяє вдвічі скоротити час сушіння і знизити на 22,4 \% питомі енерговитрати на одиницю продукції.

Сушіння при зниженій температурі теплоносія призводить до зменшення числа Ребіндера, тобто до зниження теплового навантаження на матеріал.
Число Ребіндера знижується від однієї ділянки пластини до іншої в залежності від зміни температури. За допомогою цього встановлюється зв'язок між тепло- і масообміном, що є основним рівнянням кінетики сушіння [1] для густини теплового потоку

$$
q^{*}=N^{*} \times(1+\mathrm{Rb})
$$

На рис. 3 наведений характер зміни приведеної густини теплового потоку під час сушіння чорної фарби Instant Color® Plus. 3 кривої $q^{*}=\mathrm{f}(W)$ також визначені критичні значення відносної вологості матеріалу: $W_{\text {кр1 }}=40 \%, W_{\text {кр2 }}=27 \%, W_{\text {кр3 }}=9 \%$.

Як видно з рисунку, приведена густина теплового потоку від початкової вологості до першого кри-

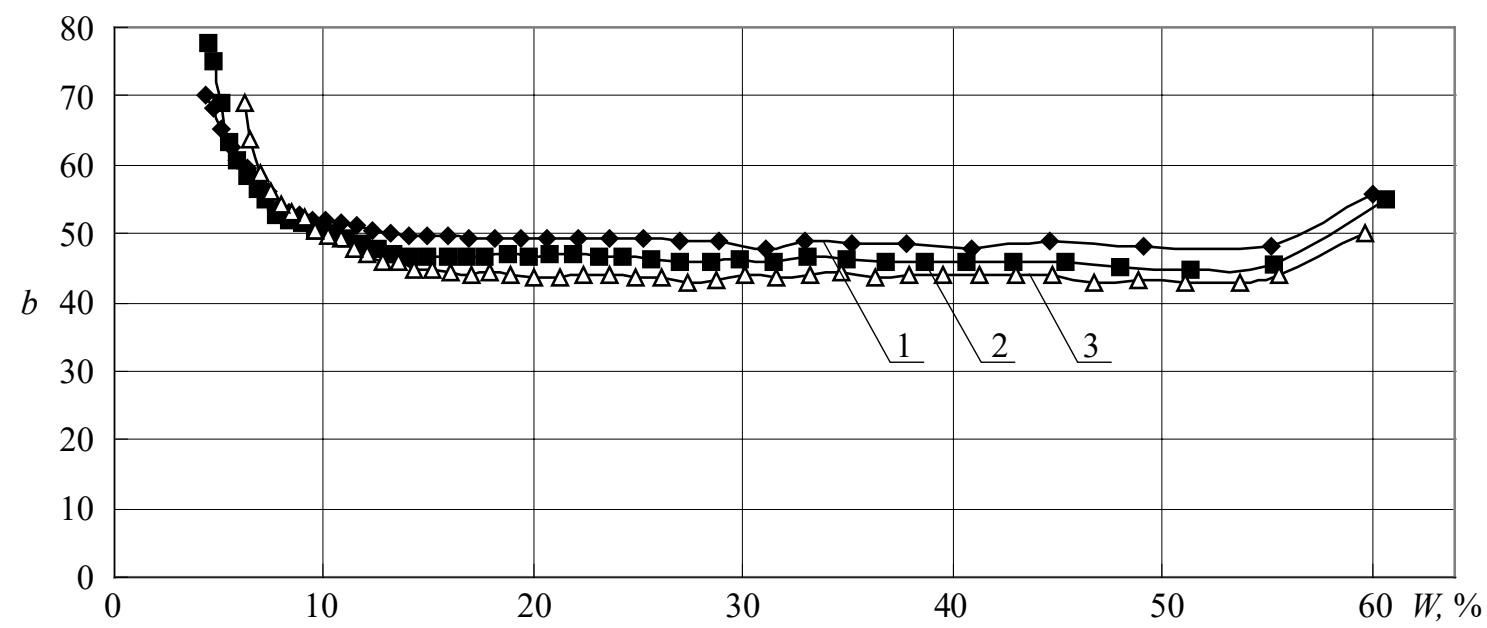

Рис. 1. Зміна температурного коефіцієнту сушіння для чорної фарби Instant Color® Plus. 1 - на першій ділянці пластини; 2 - на другій ділянці пластини; 3 - на третій ділянці пластини

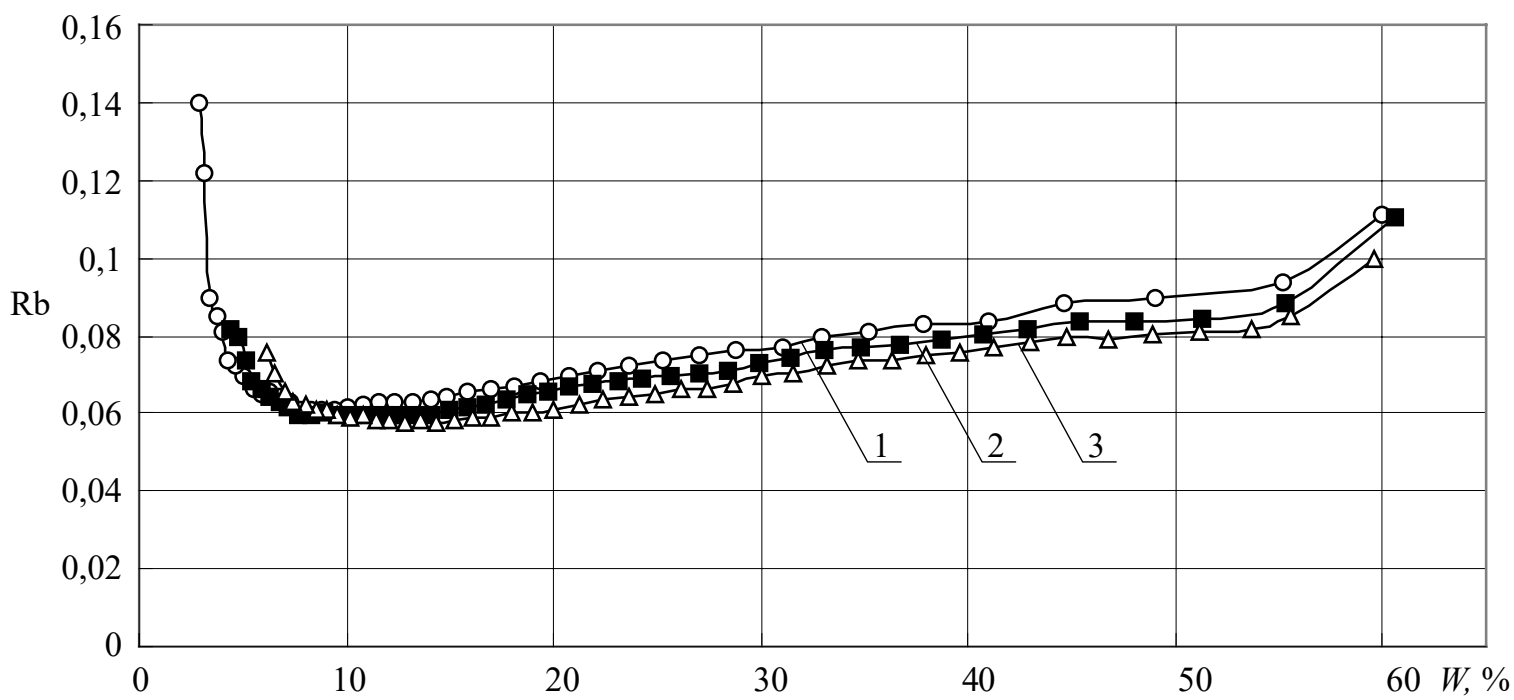

Рис. 2. Характер зміни числа Ребіндера при сушінні чорної фарби Instant Color® Plus.

1 - на першій ділянці пластини; 2 - на другій ділянці пластини; 3 - на третій ділянці пластини 
тичного значення відносної вологості $W_{\text {кр1 }}=40 \%$ змінюється за ступеневим законом

$$
q^{*}=0,0003 \cdot W^{0,195}
$$

від першого критичного значення відносної вологості $W_{\text {кр1 }}=40 \%$ до другого $W_{\text {кр2 }}=27 \%$ за лінійним законом

$$
q^{*}=0,012 \cdot W+0,008,
$$

від другого критичного значення відносної вологості $W_{\text {кр2 }}=27 \%$ до третього $W_{\text {кр3 }}=9 \%$

$$
q^{*}=0,0106 \cdot W+0,102
$$

а від третього критичного значення відносної вологості $W_{\text {кр3 }}=9 \%$ до кінцевої вологості $W_{\text {кін }}=2 \%$ закон зміни $q^{*}$ описується логарифмічною кривою

$$
q^{*}=0,116 \cdot \ln (W)-0,1285
$$

По відомим величинам $q^{*}$ можна вирахувати величину густини теплового потоку для різних режимів сушіння:

$$
q(\tau)=q^{*} \cdot q
$$

де $q=\operatorname{grad} U / d=$ const, a dU/d - максимальна швидкість сушіння шару фарби, \%/c; $r$ - питома теплота випаровування розчинника, кДж/кг; $g=m / s-$ відношення абсолютно сухої маси фарби до поверхні випаровування, кг/м².

Зміни густини теплового потоку, що витрачається на нагрівання матеріалу і на випаровування 3 нього розчинника, мають вигляд, що представлений на рис. 4.
Слід відзначити, що на густину теплового потоку не впливає хімічний склад фарби: надглазурна кольорова фарба чи люмінесцентна.

Із кривих зміни густини теплового потоку можна визначити коефіцієнти тепловіддачі $\alpha$, що наведені на рис. 5. Під час сушіння надглазурної фарби коефіцієнт тепловіддачі змінюється на 15 - $25 \%$. Він значною мірою залежить від швидкості теплоносія. Одержані величини коефіцієнту тепловіддачі надають змогу побудувати залежність $\mathrm{Nu}=\mathrm{f}(\mathrm{Re})$. Розрахунки проведені для пластини 3 нанесеними шарами як чорної, так і люмінесцентної фарби. Результати розрахунків представлені на рис. 6 .

Таким чином, процес сушіння фарби інтенсифікує теплообмін у порівнянні з теплообміном при ламінарному обтіканні пластини на 75 \%. Процеси теплообміну при сушінні фарб описуються рівнянням

$$
\mathrm{Nu}=1,15 \cdot \mathrm{Re}^{0,5} .
$$

Збільшення числа Рейнольдса Re в 3 рази призводить до збільшення числа Нусельта $\mathrm{Nu}$ в 1,7 рази.

\section{Висновки}

Аналіз температурного коефіцієнту сушіння i числа Ребіндера визначив напрямки витрат теплоти в процесі сушіння надглазурних керамічних фарб.

Встановлено, що густина теплового потоку залежить від температури і швидкості теплоносія і не залежить від хімічного складу фарб. Побудовані залежності $\alpha=\mathrm{f}(W)$ i $\mathrm{Nu}=\mathrm{f}(\mathrm{Re})$. Показано, що коефіцієнт тепловіддачі залежить від швидкості теплоносія.

У порівнянні з теплообміном при ламінарному обтіканні пластини при сушінні інтенсивність теплообміну зростає на $75 \%$.

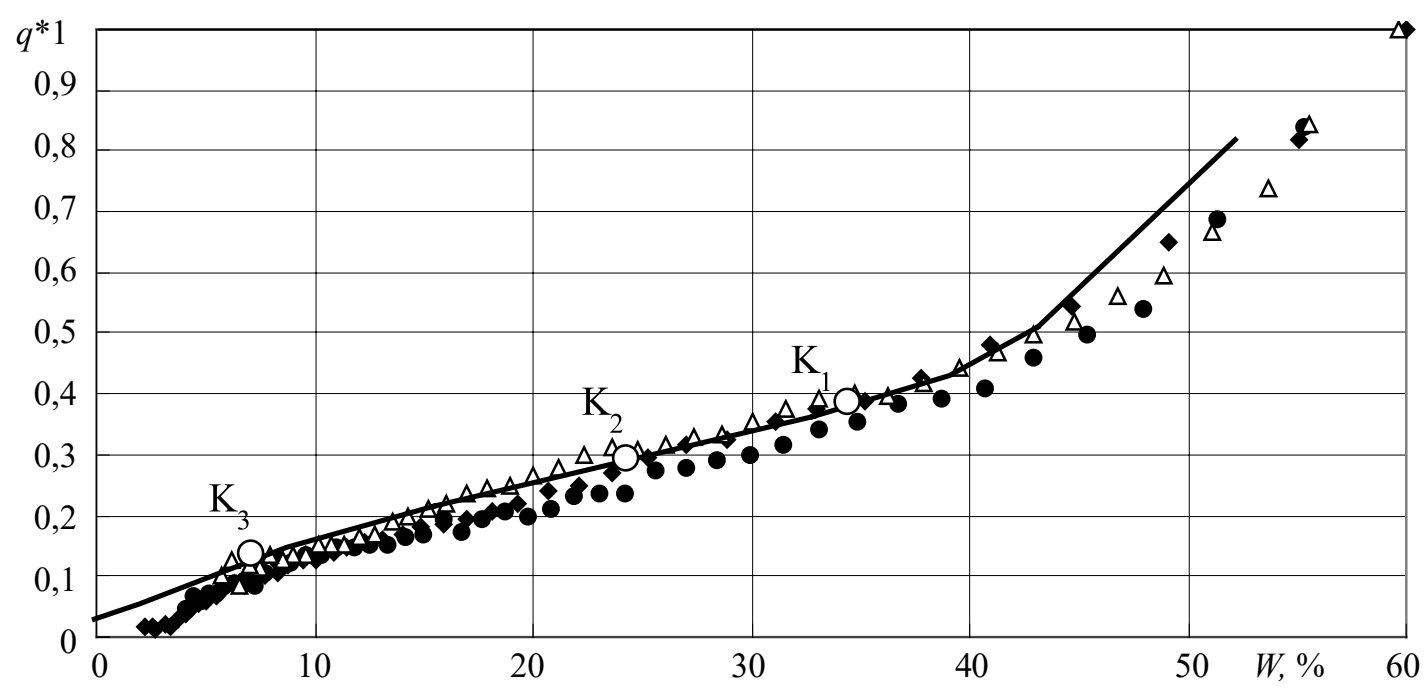

Рис. 3. Приведена густина теплового потоку при сушінні чорної фарби 


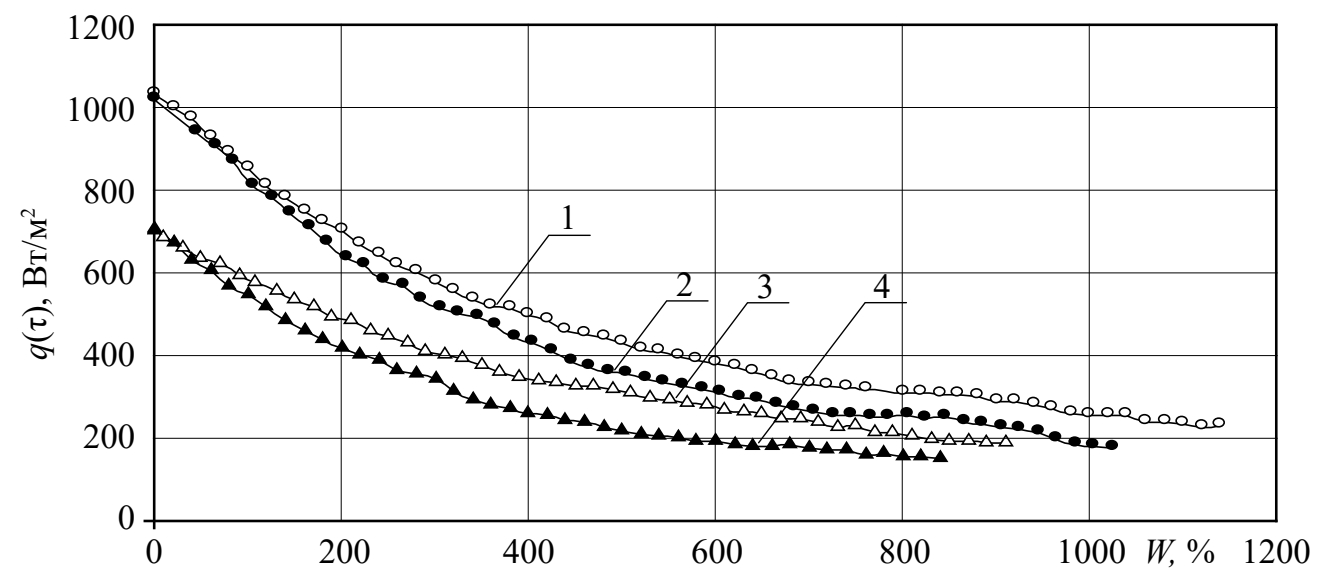

Рис. 4. Густина теплового потоку, що витрачається на нагрівання матеріалу і на випаровування розчинника з нього при різних значеннях температури $t$ швидкість потоку повітря $V$ :

$1-t=80^{\circ} \mathrm{C}, V=1 \mathrm{~m} / \mathrm{c}, d=10$ г/кг сухого повітря; $2-t=80^{\circ} \mathrm{C}, V=3 \mathrm{м} / \mathrm{c}, d=10$ г/кг сухого повітря; $3-t=60^{\circ} \mathrm{C}, V=1 \mathrm{M} / \mathrm{c}, d=10$ г/кг сухого повітря; $4-t=60^{\circ} \mathrm{C}, V=3 \mathrm{~m} / \mathrm{c}, d=10$ г/кг сухого повітря

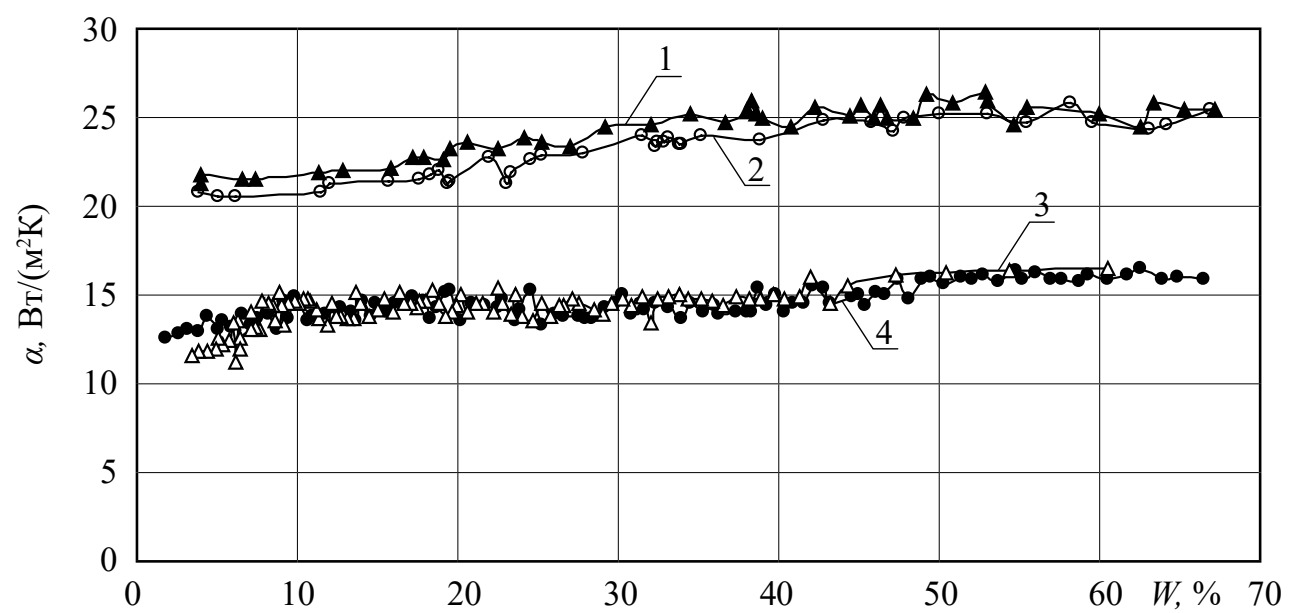

Рис. 5. Зміна коефіцієнту тепловіддачі під час сушіння чорної фарби при різних значеннях температури $t$ швидкість потоку повітря $V$ :

$1-t=80^{\circ} \mathrm{C}, V=3 \mathrm{~m} / \mathrm{c}, d=10$ г/кг сухого повітря; $2-t=60^{\circ} \mathrm{C}, V=3 \mathrm{м} / \mathrm{c}, d=10$ г/кг сухого повітря; $3-t=80^{\circ} \mathrm{C}, V=1 \mathrm{~m} / \mathrm{c}, d=10$ г/кг сухого повітря; $4-t=60^{\circ} \mathrm{C}, V=1 \mathrm{~m} / \mathrm{c}, d=10$ г/кг сухого повітря

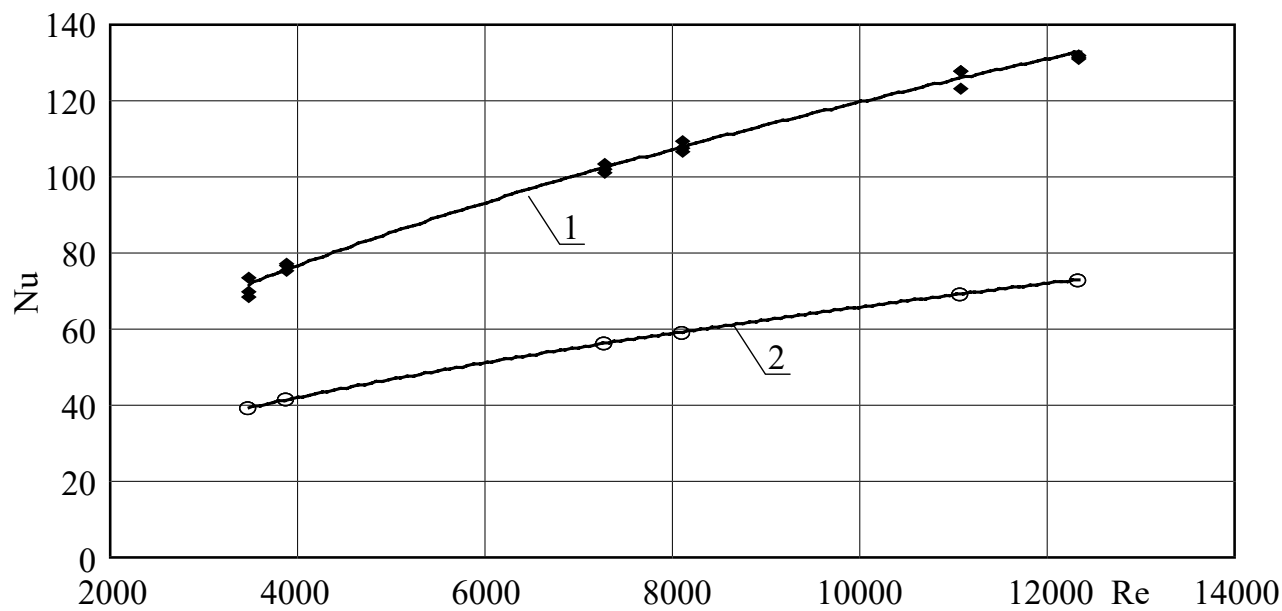

Рис. 6. Залежність $\mathrm{Nu}=\mathrm{f}(\mathrm{Re})$ при сушінні чорної і люмінесцентної фарби:

$1-\mathrm{Nu}=1,15 \mathrm{Re}^{0,5}-$ при нанесеній фарби на пластину;

$2-\mathrm{Nu}=0,66 \mathrm{Re}^{0,5}-$ при ламінарному обтіканні чистої пластини 


\section{References}

1. Лыков, А.В. Теория сушки.-М.: Энергия. - 1968.$470 \mathrm{c}$.

2. Чижский, А.Ф. Сушка керамических материалов и изделий. - М.: Стройиздат. - 1971. - 176 с.

3. Пиевский, И.М., Гречина, В.В., Назаренко, Г.Д., Степанова, А.И. Сушка керамических стройматериалов пластического формования. - К.: Наукова думка. - 1985. - 144 с.

4. Деклараційний патент України № 6848. МПК G $01 \mathrm{~N}$ 25/56 / Пристрій для визначення вмісту вологи в матеріалі. Снєжкін Ю.Ф., Рева В.І., Декуша Л.В., Воробйов Л.Й., Боряк Л.А. - Заявка № 20041210135 від 09.12.2004 р. Бюл. № 5, 2005.

5. Рева, В.И. Исследование кинетики сушки надглазурных муфельных и люминесцентных красок. Промышленная теплотехника. - 2005. - Т. 27, № 4. C.81 - 85 .

6. Снежкин, Ю.Ф., Рева, В.И., Боряк, Л.А., Декуша, Л.В., Воробьев, Л.И. Теплометрический метод исследования кинетики процесса сушки. Промышленная теплотехника. - 2005. - Т. 27, № 4. C. $72-77$. 